\title{
Unelmoivatko robotit työstä?
}

Czarniawska, Barbara \& Joerges, Bernward: Robotization of Work? Answers from Popular Culture, Media and Social Sciences. Bernward, Edward Elgar Publishing, 2020, 144 sivua.

Automatisaation työllisyysvaikutukset ovat herättäneet keskustelua aina teollisen vallankumouksen ensisysäyksistä lähtien. Jos robotiikkaa on aiemmin pelätty sinikaulusaloilla, ajankohtaisempi huolenaihe on tekoälyn vaikutukset luoviin aloihin ja asiantuntijatyöhön. Toisaalta automatisaation pelkoon limittyy myös usko robottien hyödyntämisestä seuraavaan kapitalisaatiovaikutukseen: kun robotiikka kasvattaa yritysten tuottavuutta, uusia työpaikkoja syntyy. Aivan oma keskustelunsa koskee singulariteettia; ennusteita, joilla tulevaisuudentutkijat ennakoivat hetkeä, jolloin tekoäly ylittää ihmisen kognitiiviset kyvyt niin työelämässä kuin muillakin yhteiskunnan osa-alueilla.

Professorit Barbara Czarniawska ja Bernward Joerges tarttuvat kirjassaan kysymykseen robotiikan vaikutuksista työllisyyteen. He tarkastelevat automatisaation herättämiä toiveita ja pelkoja sekä niiden muutoksia populaarikulttuurissa ja mediassa. Kirjoittajia kiinnostaa, onko käsitys roboteista pysynyt samana ja vastaako se robotiikan todellisia muutoksia. Kirjoittajat määrittelevät robotin yksinkertaisesti teknologiaksi, jolla on fyysinen ruumis, sensoreita ja tekoäly, joka prosessoi sensorien mittaamaa dataa. Tutkijoille on tärkeää, että robotti nähdään työntekijänä, joko ihmistyöläisen kaverina tai korvaajana. Yksi kirjaa läpileikkaava aihe on robotisaation ja siirtotyövoiman väliset yhteydet: miten robo- tiikka vaikuttaa naisvaltaisiin ja matalapalkkaisiin palvelualoihin, kuten siivoukseen ja hoivatyöhön.

Tutkimuksen teoreettinen pohja on mediatutkimuksessa yleisessä representaatioteoriassa. Siihen perustuen kirjoittajat ajattelevat, että robotiikan representaatiot sekä heijastelevat todellisuutta että muuttavat sitä. Kulttuuri, media ja tieteet vaikuttavat myös toistensa tuottamiin representaatioihin kehämäisesti. Robotiikkaan liittyvät myytit ja tarinat muokkaavat yhteiskuntaa laajasti, koska populaarikulttuuri saavuttaa laajemman yleisön kuin akateeminen tutkimus. Kirjoittajat väittävätkin hieman poleemisesti, että kulttuuriteollisuus vaikuttaa enemmän julkiseen keskusteluun kuin (sosiaali)tieteiden tutkimustulokset. Kirja on jaettu erilaisten aineistojen pohjalta kolmeen selkeään temaattiseen kokonaisuuteen: robotteihin populaarikulttuurissa, mediassa ja sosiaalitieteissä. Aineistojen lukutapaa ohjaa kriittinen suhtautuminen väitteisiin, joiden mukaan kehittyneet robotit aiheuttavat uuden teollisen vallankumouksen.

Kirjan ensimmäisessä osiossa keskitytään populaarikulttuuriin. Kulttuurituotteiden osalta Czarniawska ja Joerges luottavat tieteis- ja spekulatiivisen fiktion robottirepresentaatioihin. Valitut teokset ulottuvat aina robottikäsitteen isän Karel Čapekin näytelmästä R.U.R (1920) tuoreempiin teoksiin, kuten Christopher Nolanin ohjaamaan Interstellar-elokuvaan (2014). Teosten pohjalta tutkijat jäsentelevät suuntaa-antavan taksonomian vastaamaan kysymyksiin, mitä hyvää ja pahaa robotit voivat tehdä ihmisille, ja toisaalta, mitä hyvää tai pahaa ihmiset voivat tehdä roboteille. 
Taksonomiaan kuuluu neljä kategoriaa, joista esittelen työelämän kannalta kiinnostavimmat kohdat. Populaarikulttuurin perusteella robotit kykenevät "hyvään" tekemällä työtä, johon ihminen ei pysty tai joka on liian vaarallista tai epämiellyttävää ihmisille. Työntekijöinä robotit ovat myös ihmisiä parempia, nopeampia ja tehokkaampia. Robotit voivat myös vapauttaa ihmiset työstä (vaikka aineiston perusteella tämä käsitys ei ole enää yleinen). "Pahimmillaan" robotit vievät ihmisten työpaikat, mikä on niin ikään aineiston perusteella vanhentunut ajatus.

Toisen osion keskiössä ovat perinteisen median automatisaatiokeskustelut. Mediaaineiston rajaamisen suhteen tutkijat luottavat omaan subjektiiviseen kokemusasiantuntijuuteensa. Kirjoittajat ovat keränneet 175 uutista, blogikirjoitusta tai artikkelia vuosilta 2014-2017. Media-aineiston pohjalta näyttää siltä, että edellä mainittu taksonomia toistuu julkisessa keskustelussa sillä lisäyksellä, että eronteko robotiikan hyvien ja pahojen vaikutusten välillä muuttuu epäselvemmäksi. Tästä diskurssista käy esimerkiksi aineistoon mukaan valittu kirjailija Margaret Atwoodin huomio siitä, että robotit tarvitsevat energiaa toimiakseen. Kun keskustelu pyörii vain automatisaation vaikutuksissa, unohtuu suurempi yhtälö, joka koskee esimerkiksi energiataloutta. Kolmannessa, sosiaalitieteisiin perustuvassa osiossa käydään läpi kybernetiikan historiaa, tutkijoiden näkemyksiä robotiikan tulevaisuudesta ja vaikutuksista, jotka - ei niin yllättäen - ulottuvat optimismista pessimismiin, utopianäkemyksistä dystopiapelkoihin.

Yhteenvetona kirjoittajat toteavat, että automatisaatio todennäköisesti lisääntyy monella alalla, kuten terveydenhuollossa. Tämä ei välttämättä tarkoita itsenäisiä robotteja vaan yleisemmin tekoälyä ja "cobotteja", joiden kanssa ihmiset tekevät yhteistyötä. Tutkijat eivät kuitenkaan halua ennustaa, vaan tarjoavat näkökulmia siihen, mihin suuntaan keskustelu robotiikasta on menossa. Automaatio koskee rutiininomaisia töitä (sekä sini- että valkokaulusaloilla), mutta keskusteltavaa riittää myös siitä, mikä työ lopulta on rutiininomaista ja mikä ei. Katsannossa eivät korostu utopia- tai dystopianäkymät, vaan samanaikaiset hyödyt ja haitat, joita automatisaatiolla saavutetaan.

Kirja tarjoaa kokonaisvaltaisen näkemyksen ajankohtaisista automatisaatiokeskusteluista eri areenoilla. Robottirepresentaatioiden erilaisiin kehävaikutuksiin perustuva tulokulma on oivallinen ja toimiva. Sen avulla tutkijat osoittavat, että fiktio vaikuttaa oleellisesti niin julkiseen keskusteluun, robotiikkaan kohdistuviin toiveisiin ja pelkoihin kuin tutkimukseenkin. Julkisessa keskustelussa mielikuvat ovat todellisia teknologioita tai tieteellisiä tutkimustuloksia voimakkaampia vaikuttajia.

Koska huomion kohteena ovat robotiikan "hyvät" ja "pahat" vaikutukset, lukija olisi kuitenkin odottanut etiikan tai moraaliteorioiden huomioimista - varsinkin kun tekoälyn etiikka on omiaan herättämään keskustelua. Kirjassa hyvä ja paha redusoituvat vain automatisaation herättämäksi toivoksi tai peloksi. Dualistinen tarkastelu synnyttää paljon kysymyksiä. Voiko robotiikka aiheuttaa muita tunteita, ja ovatko tunnereaktiot ylipäänsä riittävä perusta automaation tarkastelulle? Tekoälyn kehittyessä ja arkipäiväistyessä on mahdollista, että siitä tulee musta laatikko: oleellinen, mutta näkymätön osa yhteiskuntien toimintaa. Tällöin hyvien ja pahojen seurausten näkökulma on riittämätön.

Myös ajallinen vertailu jää teoksessa vähäiseksi. Lukijalle on epäselvää, mitä muutoksia keskustelussa on tapahtunut. Lisäksi kirjaa vaivaa geneerisyys: näkökulma tuntuu painottuvan enemmän julkisen (anglosaksisen) keskustelun alueelle kuin akateemisiin kädenvääntöihin, varsinkaan millään erityisellä tieteenalalla. Lähestymistavan voi ajatella edustavan poikkitieteellisyyden ihannetta - tutkijat itse tulevat hallintotieteiden ja sosiologian aloilta - mutta aiheen laajuuden vuoksi jää epäselväksi, mikä on kirjan kontribuutio jo olemassa oleviin keskusteluihin. Argumentaation kaari tuntuu katkeavan varsinkin loppua kohden. Kirjoittajat eivät keksi kovinkaan omaperäistä sanottavaa kokonaisaineistonsa pohjal- 
ta. Esitys muistuttaa kokoavaa referaattia ja synteesi jää puolitiehen.

Kirjan suurimmat ongelmat ovat kuitenkin sen analyysissä ja metodologiassa. Salaperäisyys vaivaa tehtyjä menetelmällisiä valintoja ja niiden oikeuttamista. Esimerkiksi kirjan populaarikulttuuria käsittelevässä osassa kulttuurituotteiden juonikuvioita ja robottihahmoja selostetaan pitkällisesti, mutta varsinainen analyysi jää alustavan taksonomiataulukon varaan, jota sitäkin avataan vain pintapuolisesti. Analyysin leväperäisyys ja hämäryys vaivaa myös kirjan mediaa ja sosiaalitieteitä käsitteleviä osia. Vaikka kirjan kaksi ensimmäistä osiota muodostavat loogisen kokonaisuuden, sosiaalitieteiden näkemyksiin pohjaava kokonaisuus jää irralliseksi. Muodostettu taksonomia ei yhtäkkiä olekaan enää mukana robotiikan hyvyyden ja pahuuden arvioinnissa, vaan osiossa tyydytään referoimaan julkaisuja robotiikasta täsmentämättä, mitä sosiaalitieteillä tarkoitetaan. Pitkät suorat lainaukset jäävät leijumaan ilmaan, eikä niitä sen tarkemmin avata. Tämä tekee osiosta raskaslukuisen.

Käytetyn metodologian avaaminen jää kokonaisuudessaan puutteelliseksi. Esimerkiksi aineistojen valinta vaikuttaa summittaiselta. Kuten kirjoittajat huomioivat, robotiikkaa käsittelevät kulttuuriteokset muodostavat valtavan aineiston. He käyttävätkin valintaperusteena töiden "merkittävyyttä" ja "maailmanlaajuista suosiota". Perusteet tuntuvat riittämättömiltä 12 teoksen (ja teoskokonaisuuden) valintaan. Pintapuolisia perusteluja löytyy sille, miksi Star Wars on parempi kuin Star Trek, mutta kavalkadista puuttuu esimerkiksi suosittu Terminaattori-elokuvasarja, jossa singulariteetin saavuttaneen tekoälyn (pelottaviin) vaikutuksiin puututaan suoraan. Sama hämäräperäisyys koskee media-aineiston valintaa: sitä perustellaan vielä vähemmän, vaikka potentiaalinen aineisto on vielä laajempi. Esimerkiksi rajaus vuosiin 2014-2017 jää perustelematta, ja subjektiivinen lähestymistapa tuntuu enemmän laiskuudelta kuin täsmälliseltä metodilta.

Jos teoslistaa tarkastelee kriittisesti, edustaa se silmiinpistävän länsimaista kulttuuriperintöä. Mielenkiintoista olisi ajallisen vertailun lisäksi vertailu myös maiden ja kulttuurien välillä. Viitteitä tästä annetaan kirjan kolmannessa osiossa, jossa alustavasti vertaillaan erilaisia robottikäsityksiä länsimaissa ja varsinkin hoivarobotiikkaan panostaneessa Japanissa. Vaikka kirjassa on nähtävissä pyrkimys laaja-alaisuuteen, ovat tulokset metodologisista valinnoista johtuen väistämättä vinoutuneita ja esimerkinomaisia. Ongelma ei olisi niin suuri, jos menetelmällisiä valintoja olisi perusteltu enemmän ja saatujen tulosten vaikutusaluetta täsmennetty.

Jos populaarikulttuuri on innostanut kirjoittajia, näkyy populaaritieteellinen kirjoittamistyyli myös kirjan kokonaisuudessa. Teos on parhaimmillaan tietokirjamainen katsaus kapeasti määritellyn robotiikan representaatioihin joissakin länsimaisen populaarikulttuurin teoksissa, perinteisen median julkaisuissa ja hyvin rajallisissa tieteellisissä keskusteluissa.

\section{Kirjoittaja}

Joni Jaakola, VTM, tohtorikoulutettava, Turun yliopisto, sähköposti: jomijaa@utu.fi 